\title{
Use of ICT by Biology Teachers in the Secondary Schools: Bangladesh Perspective
}

\author{
Zeba Farhana* Sabbir Ahmed Chowdhury \\ Assistant Professor, Institute of Education and Research (IER), University of Dhaka, Dhaka - 1000, Bangladesh
}

\begin{abstract}
Information and communication technologies (ICT) have changed the pedagogy in education offering more student-centered learning incidents. The purpose of this study was to evaluate the use of ICT by the biology teachers in teaching-learning process of secondary schools in Bangladesh. A total of 50 biology teachers from several secondary schools of Bangladesh participated in the study. It was found that teachers have better access to computer than the average populace of Bangladesh. They have working knowledge on Microsoft Office Word, Excel, Power Point, and different web browsers. A good number of the teachers use computer for preparing their lectures, use internet for accessing educational materials, takes classes with multimedia with the support of ICT. However, about $17 \%$ to $25 \%$ were found to be not using these ICT means. Many teachers opined that they have less number of computers in the school to prepare for class work. They also assessed that hardware troubleshooting, software malfunction and unexpected power failure as challenges for using ICT. This paper recommends to provide continuous in-servicing training on ICT, interest free loan to teachers for purchasing laptop computer and to ensure technical support to overcome software and hardware problems in the schools.
\end{abstract}

Keywords: ICT in education, teaching learning process, biology teachers, secondary school.

DOI: $10.7176 / \mathrm{JCSD} / 45-05$

\section{Introduction}

We are living in $21^{\text {st }}$ century, which encompasses the Information Age - an era marked by rapid adoption of new technologies (Holland, 2015). Many new technologies, Information and Communication Technology (ICT henceforth) being the forerunner, have influenced the way we live, communicate, socialize, learn or educate. Introduction of ICT in almost all the sectors of our lives have created a new global economy that is powered by technology, fueled by information and driven by knowledge (US Department of Labour, 1999). Advent of the knowledge economy and global economic competition compel governments to prioritize educational quality, lifelong learning and the provision of educational opportunities for all. It is widely accepted that access to ICT in education can help individuals to compete in a global economy by creating a skilled work force and facilitating social mobility (Wallet \& Melgar, 2014).

Leaving the Least Developed Countries (LDC) category towards developing country, Booming Bangladesh is striving to improve its education system for the knowledge era (United Nations, 2018). The Government of Bangladesh $(\mathrm{GoB})$ aiming to turn the huge number of its potential young intelligent populace into a resourceful one, has emphasized on ICT in education by introducing 'multimedia classrooms', 'teacher-led content development', e-learning module, interactive digital text etc in primary schools, secondary schools and madrashas (religious schools) across the country according to the Master Plan for ICT in Education (Ministry of Education GoB, 2013).

As biology includes complex relationships of unfamiliar and abstract concepts, it is quite difficult to learn and teach. Students often experience difficulty in understanding certain biological subjects and try to learn them via memorization without understanding (Kilic \& Salam, 2004). But the use of ICT can help understanding a difficult subject easily. A survey in Bangladesh has shown that learning becomes interesting and lively through using multimedia equipments in the classroom through active participation of learners in the learning process (PMID, 2013). It is especially important in biology as computers can present the information visually through well-prepared pictures, three-dimensional models, animations, interactive environments etc (Wang Q. , 2017).

Teachers play a crucial role in the adoption and implementation of new technologies in education. Their perceptions are an important aspect that influences their adoption of ICT in teaching and learning (Zhu, 2010), because teachers' educational beliefs are closely linked to their actual use of ICT in classrooms (Dwyer, Ringstaff, \& Sandholtz, 1991) (Tondeur, Valcke, \& Van Braak, 2008). The quality of teachers and their continuing professional education and training remain central to the achievement of quality education (Ministry of Education GoB, 2013). Understanding this fact, GoB regularly arranges teachers' training on ICT (Mamataz, 2017) (PMID, 2013). Moreover, Digital Content Development has also been undertaken so that all teachers can collect subject based contents from a single source, for which an official web portal named ShikkhokBatayon (www.teachers.gov.bd) has been opened (Mamataz, 2017) (Ministry of Education GoB, 2013) (PMID, 2013) (Shikkhok Batayon, 2018). With this backdrop, the aim of this study is to evaluate the preparation, practice and challenges of biology teachers on using ICT for teaching learning purpose in the secondary schools of Bangladesh. 


\section{Objectives}

The objectives of the study are as follows:

1. To assess whether secondary school's biology teachers have access to ICT for school work.

2. To assess the ICT knowledge level of biology teachers teaching at the secondary school in Bangladesh.

3. To find out the use of ICT by these teachers for teaching learning purpose.

4. To determine the challenges faced by them in using ICT for teaching and learning process.

\section{Methodology}

The research framework led us methodologically to design a quantitative method according to research objectives to compile the whole picture. For accomplishing the study, a survey questionnaire was used to collect information from the teachers teaching biology at the secondary schools in Bangladesh. A total of 50 teachers from secondary schools of eight divisions (40 districts) of Bangladesh were randomly selected to carry out this study. The survey questionnaire was divided mainly into two parts, where the first part deals with age, gender and teaching experience of the teachers. The second part was designed to gather information about their knowledge on ICT and its educational application, attitude towards use of ICT and the challenges they face while using ICT for teaching learning purpose. Collected data were analyzed using Microsoft Office Excel and the results were compared with existing literatures.

\section{Results}

Information has been collected from biology teachers of secondary schools in Bangladesh. Table 1 categorizes surveyed teachers according to gender, age group and teaching experience.

Table 1. Profile of Surveyed Biology Teachers $(\mathrm{N}=50)$

\begin{tabular}{|l|l|c|}
\hline Variables & & Percentage \\
\hline \multirow{3}{*}{ Gender } & Male & $58 \%$ \\
\cline { 2 - 3 } & Female & $42 \%$ \\
\cline { 2 - 3 } & $<=30$ & $20 \%$ \\
\cline { 2 - 3 } & $31-40$ & $42 \%$ \\
\cline { 2 - 3 } & $41-50$ & $34 \%$ \\
\hline \multirow{4}{*}{ Teaching Experience (years) } & $50>$ & $4 \%$ \\
\cline { 2 - 3 } & $1-5$ & $28 \%$ \\
\cline { 2 - 3 } & $6-10$ & $18 \%$ \\
\cline { 2 - 3 } & $11-15$ & $16 \%$ \\
\cline { 2 - 3 } & $16-20$ & $30 \%$ \\
\hline
\end{tabular}

Findings of our study are described in the following sections.

\subsection{Access to ICT for School Works}

The teachers were asked to respond on a three point scales- Always, Sometimes and Never on the questions whether they have access to computer and internet at home and at school when these are required for school works.

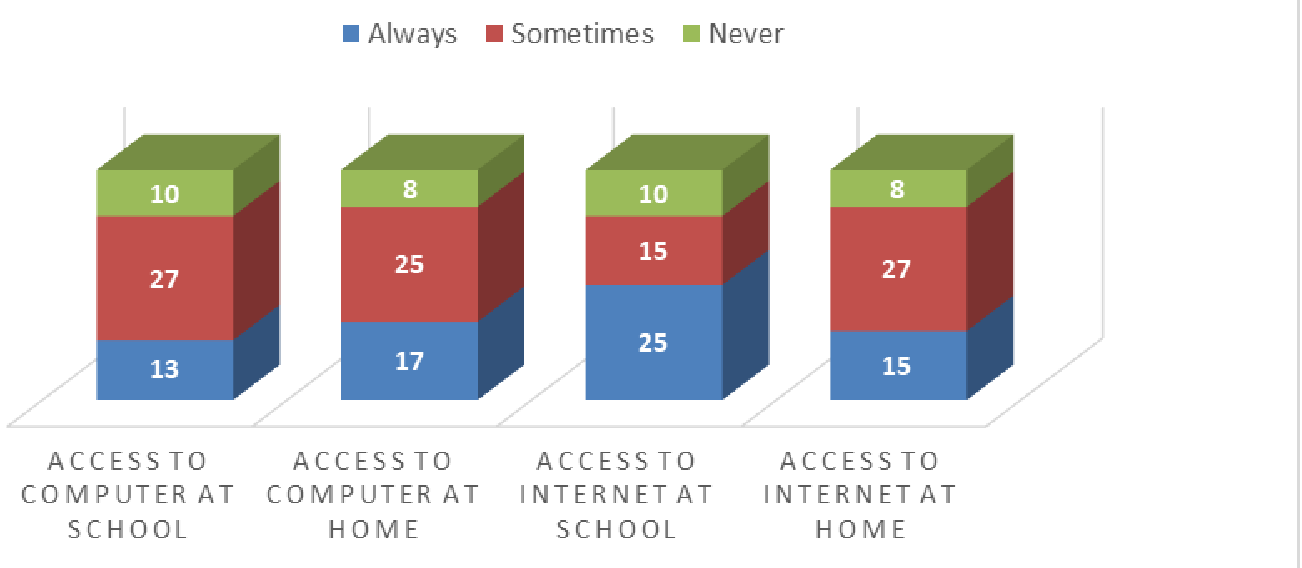

Figure 1. Access to ICT

According to Figure 1, most of the biology teachers have access to computer at school (27\% always and $54 \%$ sometimes) and at home (35\% always and 50\% sometimes). They also have internet connections at school (50\% always and $31 \%$ sometimes) and at home (31\% always and 54\% sometimes). However, a good number of 
teachers responded that they do not have access to computer or internet at school (19\%) and at home (15\%).

\subsection{ICT Knowledge of Biology Teachers}

The surveyed teachers were asked to rate their knowledge on few basic software applications such as word processing, spreadsheet, presentation software, e-mailing, internet browsers etc.

Table 2. Survey Response about ICT Knowledge of Biology Teachers

\begin{tabular}{|l|c|c|c|c|c|}
\hline \multirow{2}{*}{ Software Application } & \multicolumn{5}{|c|}{ Percent (\%) } \\
\cline { 2 - 6 } & Excellent & Very Good & Good & Satisfactory & Nil \\
\hline Word Processor (MS Word) & 6.00 & 26.00 & 24.00 & 32.00 & 12.00 \\
\hline Spreadsheet (MS Excel) & 2.00 & 6.00 & 24.00 & 48.00 & 20.00 \\
\hline Presentation Software (MS PowerPoint) & 6.00 & 26.00 & 28.00 & 28.00 & 12.00 \\
\hline Web Browsers & 4.00 & 18.00 & 30.00 & 36.00 & 12.00 \\
\hline Computer Maintenance & 0.00 & 0.00 & 6.00 & 8.00 & 86.00 \\
\hline
\end{tabular}

Table 2 shows the response of the teachers in percentile under five scales i.e. Excellent, Very Good, Good, Satisfactory and Nil. It was found that $82 \%$ respondents assessed their knowledge on Microsoft Office Word either very good $(26 \%)$, good $(24 \%)$ or satisfactory $(32 \%)$. Likewise, $78 \%$ teachers assessed their knowledge in between very good and satisfactory on Spreadsheet. About $82 \%$ biology teachers responded that their knowledge on Presentation Software were very good (26\%), good $(28 \%)$ or satisfactory $(28 \%)$. Similarly, $84 \%$ teachers rated their skills on web browsers as very good $(18 \%)$, good $(30 \%)$ or satisfactory $(36 \%)$. But, most of the teachers $(86 \%)$ did not have any knowledge on the software/hardware maintenance of computer. It is also to be noted that a good portion of teachers do not possess knowledge on any of these software applications; $20 \%$ teachers did not know the application of spreadsheet, 12\% teachers did not know word processor, presentation software or internet. Hence, in-servicing training can be helpful to improve teachers' ICT skills.

\subsection{Use of ICT for Teaching Learning Purpose}

The teachers were asked how they use ICT for teaching learning process and their responses are shown in Table 3.

Table 3. Use of ICT for Teaching Learning Purpose.

\begin{tabular}{|l|c|c|c|}
\hline \multirow{2}{*}{ Purpose } & \multicolumn{3}{|c|}{ Percent (\%) } \\
\cline { 2 - 4 } & Often & Seldom & Never \\
\hline Accessing educational Materials from internet & 12.00 & 64.00 & 24.00 \\
\hline Making Presentation & 16.00 & 67.00 & 17.00 \\
\hline
\end{tabular}

It was found that $64 \%$ teachers seldom use internet for accessing educational materials; whereas, $12 \%$ teachers often and $24 \%$ teachers never use internet for the same purpose. It was also found that $67 \%$ teachers seldom take class by using multimedia projectors. But $17 \%$ teachers had never made any presentation by help of ICT.

Further the teachers were asked how often they have used the computer in last three years in their preparation for school work and their reply is shown in Figure 2. $40 \%$ of the teachers admitted that they had used computer at least once or twice a week in last three years while preparing their lectures or making presentation in the class. $20 \%$ teachers used computers once or twice a month and $16 \%$ teachers used computers a few times in a year for the same purpose. But $24 \%$ teachers never used computer for any such purpose.

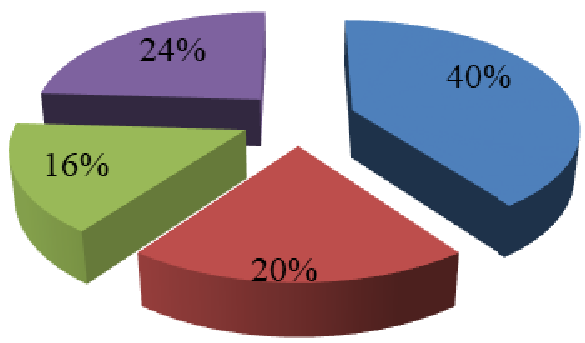

Once or twice a week

Once or twice a month

A few times in a year

- None

Figure 2. Usage of the computer in last three years in preparation for school work

In addition, the teachers were also asked how many classes they had taken with the support of ICT in the last year and responses are shown in Figure-3. 


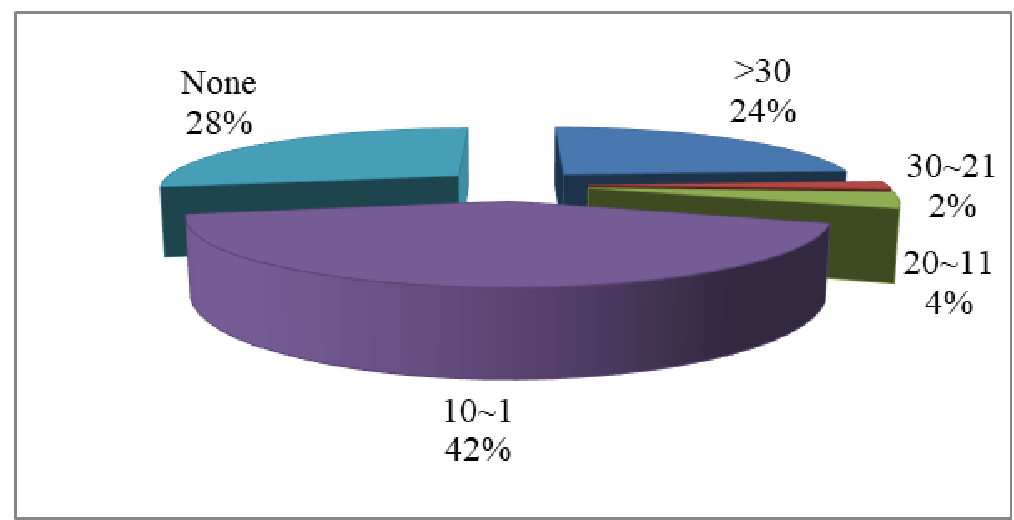

Figure 3. Classes taken with the support of ICT in 2017

It was found that $24 \%$ teachers took more than 30 classes in last year (2017) with the support of ICT. However, $42 \%$ teachers took only 1 to 10 classes and $28 \%$ teachers did not take any class in that year.

\subsection{Challenges faced by Biology Teachers in using ICT}

Several challenges were identified during the study, which are shown in Table 4.

Table 4. Challenges Faced to use ICT by the teachers

\begin{tabular}{|c|c|c|c|c|c|}
\hline \multirow[t]{2}{*}{ Challenges } & \multicolumn{5}{|c|}{ Percent $(\%)$} \\
\hline & SA & $\mathrm{A}$ & $\mathrm{N}$ & $\mathrm{D}$ & SD \\
\hline Lack of technical support on hardware and software problem & 58 & 30 & 8 & 4 & 0 \\
\hline Unexpected power failure during class hour & 32 & 52 & 6 & 8 & 2 \\
\hline Lack of computer in school & 24 & 42 & 24 & 6 & 4 \\
\hline Unable to manage time to share computer in school & 28 & 42 & 20 & 8 & 2 \\
\hline Limited knowledge on how to make full use of ICT & 4 & 20 & 28 & 36 & 12 \\
\hline
\end{tabular}
$\mathrm{SA}=$ Strongly Agree, $\mathrm{A}=$ Agree, $\mathrm{N}=$ Neutral, $\mathrm{D}=$ Disagree and $\mathrm{SD}=$ Strongly Disagree

Lack of technical support on hardware and software problem was found to be the biggest challenge for the teachers. 58\% teachers strongly agree and 30\% teachers agree that unserviceability of computer and software malfunction hinder their use of ICT in the class room. The second biggest challenge was identified as the unexpected power failure during class hour, which was strongly agreed by $32 \%$ teachers and agreed by $52 \%$ teachers. Most of the teachers opined (24\% strongly agreed and $42 \%$ agreed) that they have less number of computer in their school. They (28\% strongly agreed and $42 \%$ agreed) also expressed that they were unable to manage time to share very limited number of school computers. However, many teachers disagreed $(12 \%$ strongly disagreed and $36 \%$ agreed) that they have limited knowledge on how to make full use of ICT in teaching learning process.

\section{Discussions}

Finding shows that most of the biology teachers have access to computer at school (27\% always and $54 \%$ sometimes) and at home (35\% always and 50\% sometimes), which is far better than the fact that only $8 \%$ Bangladeshi household owns a computer (Pew Research Center, 2015). They also have better internet access at school (50\% always and $31 \%$ sometimes) and at home (31\% always and 54\% sometimes) as compared to the statistics i.e. only 10\% Bangladeshi have access to internet (Pew Research Center, 2015). GoB has already established 24,816 multimedia classrooms, provided internet connection to almost $90 \%$ schools and set up multimedia classroom monitoring system (a2i Programme GoB, 2018). Even though, Most of the biology teachers opined that they have less number of computer in their school. They were unable to manage time to prepare the lecture by using school computers. It is sometimes difficult for them to arrange classes by using multimedia projector due to limited number of school computer. Though forty percent teachers used computer at least once or twice a week in last three years while preparing their lectures or making presentation in the class, $24 \%$ teachers are yet to use computer for this purpose and $17 \%$ teachers had never taken any class with the help of ICT.

While evaluating the knowledge level, it was evident that teachers have working knowledge on Microsoft Office Word, Excel, Power Point, and different web browsers. Access to Information project of GoB has played an important role to impart training to school teachers (PMID, 2013). However, It is also to be noted that a good portion of teachers (12 to 20\%) do not possess knowledge on any of these software applications. Although, most of the teachers use internet for accessing educational materials, 24\% teachers are still not using internet for educational purpose. GoB's effort of Multimedia classroom monitoring system (a2i Programme GoB, 2018) 
resulted in to $24 \%$ teachers taking more than 30 classes in last year (2017) with the support of ICT. Another $42 \%$ teachers took only 1 to 10 classes in that year. However, $28 \%$ teachers did not take any class in 2017 with the support of ICT. Hence, in-service training can be arranged continuously to impart ICT skills to these teachers.

Although around 4000 contents on biology class-lectures are developed by the teachers of different schools and colleges (ShikkhokBatayon, 2018), the respondent teachers of this study did not find enough opportunity to harness the benefits of such huge initiatives of GoB due to less number of computers available for individual teachers. If number of computer is increased in school or every school teacher is equipped with a computer, then they can prepare their lecture at home or during the free time of the school and take class with the help of computer and multimedia projector. GoB may consider providing interest free loan to the teachers to purchase a laptop computer to shift the role of the teacher from the "sage on the stage" to a "guide on the side".

Another important point is that most of the teachers $(86 \%)$ did not have any knowledge on the software/hardware maintenance of computer. As such, their biggest challenge is to cope up with hardware troubleshooting, software malfunction and unexpected power failure during class hour. Although, GoB has allotted a lump-sum amount for operation and maintenance of the computer and multimedia equipment as well as one year warranty has been given for these equipment (PMID, 2013), these steps were not found sufficient enough to run the multimedia classroom smoothly. Substantial effort is required to ensure technical support to overcome software and hardware problems faced by the teachers.

\section{Conclusion}

GoB has introduced ICT in education system through setting up multimedia classrooms in number of schools, arranging ICT training for school teachers, developing digital contents by the teachers etc. However, almost one fourth of the teachers are yet to use ICT for teaching learning purpose. To overcome the situation, GoB may arrange continuous in-service training for the teachers, provide interest free loan to school teachers for purchasing laptop computers and to ensure technical support to overcome software and hardware problems in the schools.

\section{References}

a2i Programme GoB. (2018, April 08). Home: Multimedia Classroom Monitoring System. Retrieved November 04, 2018, from Access to Information (a2i) Programme Website: http://mmcm.gov.bd/

Access to Information Programme, Government of Bangladesh. (n.d.). a2i. Retrieved September 25, 2018, from Assessment of Multimedia Classrooms (MMC) and Teacher-led Content Development: https://a2i.gov.bd/publication/assessment-of-multimedia-classrooms-mmc-and-teacher-led-contentdevelopment/

Balanskat, A., Blamire, R., \& Kefala, S. (2006). The ICT impact report: a review of studies of ICT impact on schools in Europe. Brussels: European Schoolnet.

Becker, H. J. (2000). Pedagogical Motivations for Student Computer Use That Lead to Student Engagement. Educational Technology, 40(5), 5-17.

Blurton, C. (1999). New Directions of ICT use in Education. UNESCO World Communication and Information Report.

du Plessis, A., \& Webb, P. (2012). Teachers' perceptions about their own and their schools' readiness for computer implementation: A South African case study. Turkish Online Journal of Educational Technology, $11(3)$.

Dunn, S. L. (2003). The Information Age May Make Traditional Universities Obsolete. In J. D. Torr, The Information Age (p. 138). Farmington Hills: Greenheaven Press.

Dwyer, D. C., Ringstaff, C., \& Sandholtz, J. H. (1991). Changes in teachers' beliefs and practices in technologyrich classrooms. Educational Technology, 48(8), 45-52.

Farrukh, S., \& Singh, S. P. (2014, November). Teachers Attitude Towards Use of ICT in Technical and NonTechnical Institutes. Journal of Education and Social Reasearch, IV(7), 153-160.

Goktas, Y., Yildirim, Z., \& Yildirim, S. (2009). Investigation of K-12 Teachers' Competencies and the Contributing Factors in Acquiring These Competencies. The New Educational Review, 17(1), $276-94$.

Gunawardena, C., Lowe, C., \& Anderson, T. (1997). Analysis of a global online debate and the development of an interaction analysis model for examining social construction of knowledge in computer conferencing. Journal of Educational Computing Research, 17(4), 397-431.

Gupta, M. M. (2015). Attitude of Prospective Teachers towards the Use of Information and Communication Technology (ICT) in Teacher Education. International Journal of Scientific Research Engineering \& Technology (IJSRET), 117-121.

Hinson, J., Laprairie, K., \& Heroman, D. (2006). A failed effort to overcome tech barriers in a K-12 setting: What went wrong and why. International Journal of Technology in Teaching and, 2(2), 148-158.

Holland, B. (2015, October 15). Oporationalizing the Information Age, Knowledge Economy, 21st Century. 
Retrieved September 29, 2018, from EdTech Researcher, The Education Week's blog: https://blogs.edweek.org/edweek/edtechresearcher/2015/10/operationalizing.html

Kilic, D., \& Salam, N. (2004). The effect of concept maps on learning success and permanence in biology education. Journal of Education, 27, 155-164.

Kirschner, P., Strijbos, J. W., Kreijns, K., \& Beers, P. J. (2004). Designing electronic collaborative learning environments. Educational Technology: Research and Development, 52(3), 47-66.

Korte, W., \& Hüsing, T. (2006). Benchmarking Access and Use of ICT in European Schools 2006: Results from Head Teacher and A Classroom Teacher Surveys in 27 European Countries. Empirica.

Lloyd, M. (2005). Towards a definition of the integration of ICT in the classroom. Proceedings AARE '05 Education Research - Creative Dissent: Constructive Solutions. Parramatta, NSW.

Mamataz, I. A. (2017, March 05). Use of multimedia in classroom: Successes and challenges. Retrieved September 25, 2018, from The Daily Sun: http://www.dailysun.com/printversion/details/209947/2017/03/05/Use-of-multimedia-in-classroom:-Successes-andchallenges

Mamun, M., \& Tapan, S. (2009). Using ICT in Teaching-Learning at the Polytechnic Institutes of Bangladesh: Constraints and Limitations. Teacher's World-Journal of Education and Research, 33-34, 207-217.

Mandell, S., Sorge, D., \& Russell, J. (2002). Tips for technology integration. TechTrends, 46(5), $39-43$.

Ministry of Education GoB. (2013). Master Plan for Information and Communication Technology in Education (2012-2021). Dhaka: Ministry of Education, GoB.

Mndzebele, N. (2013). Teachers Readiness in Using ICT in the Classroom: The Case of a Developing Country. International Journal of Information and Education Technology, 3(4), 409-412.

Pew Research Center. (2015). Spring 2014 Global Attitudes Survey. Washington, DC 20036: Pew Reasearch Center. Retrieved from Pew Research Center: http:/www.pewglobal.org/dataset/2014-spring-globalattitudes/

PMID. (2013). Assessment of Multimedia Classrooms (MMC) and Teacher-Led Content Development. Dhaka: A2i Programme, UNDP Bangladesh.

Salehi, H., \& Salehi, Z. (2012). Challenges for Using ICT in Education: Teachers' Insights. International Journal of e-Education, e-Business, e-Management and e-Learning, 2(1), 40-43.

Salmon, G. (2004). E-Moderating: The key to online teaching and learning (2nd ed.). London: Taylor \& Francis.

Shikkhok Batayon. (2018, September 25). Biology. Retrieved September 25, 2018, from Shikkhok Batayon: https://www.teachers.gov.bd/subject/\%E0\%A6\%9C\%E0\%A7\%80\%E0\%A6\%AC$\% \mathrm{E} 0 \% \mathrm{~A} 6 \% \mathrm{AC} \% \mathrm{E} 0 \% \mathrm{~A} 6 \% \mathrm{BF} \% \mathrm{E} 0 \% \mathrm{~A} 6 \% 9 \mathrm{C} \% \mathrm{E} 0 \% \mathrm{~A} 7 \% 8 \mathrm{D} \% \mathrm{E} 0 \% \mathrm{~A} 6 \% 9 \mathrm{E} \% \mathrm{E} 0 \% \mathrm{~A} 6 \% \mathrm{BE} \% \mathrm{E} 0 \% \mathrm{~A} 6 \% \mathrm{~A} 8$

Stensaker, B., Maassen, P., Borgan, M., Oftebro, M., \& Karseth, B. (2007). Use, updating and integration of ICT in higher education: Linking purpose, people and pedagogy. Higher Education, 54, 417-433.

Tabata, L., \& Johnsrud, L. (2008). The Impact of Faculty Attitudes Towards Technology, Distance Education and Innovatiion. Research in Higher Education, 49(7), 625-646.

Tondeur, J., Valcke, M., \& Van Braak, J. (2008). A multidimensional approach to determinants of computer use in primary education: teacher and school characteristics. Journal of Computer Assisted Learning, 24(6), 494-506.

Toprakci, E. (2006). Obstacles at integration of schools into information and communication technologies by taking into consideration the opinions of the teachers and principles of primary and secondary schools in Turkey. Journal of Instructional Science and Technology (e-JIST), 9, 1-16.

UNB. (2012, May 21). 1,000 multimedia classrooms start journey. Retrieved September 25, 2018, from The Daily Star: https://www.thedailystar.net/news-detail-235038

UNESCO. (2007). The UNESCO ICT in Education Programme. UNESCO Bangkok.

United Nations. (2018, March 13). Department of Economic and Social Affairs. Retrieved September 30, 2018, from United Nations Web site: https:/www.un.org/development/desa/en/news/policy/leaving-the-ldcscategory-booming-bangladesh-prepares-to-graduate.html

US Department of Labour. (1999, May 01). Futurework Report. Retrieved September 29, 2018, from US Department of Labour: https://www.dol.gov/oasam/programs/history/herman/reports/futurework/report.htm

Wallet, P., \& Melgar, B. V. (2014). Information and Communication Technology (ICT) in Education in Asia. Montreal: UNESCO Institute for Statistics.

Wang, Q. (2008). A generic model for guiding the integration of ICT into teaching and learning. Innovations in Education and Teaching International, 45(4), 411-419.

Wang, Q. (2017). Design of 3D Animation Special Effects in Animation 3D Modeling Teaching Based on QFD Theory. International Journal of Emerging Technologies in Learning, 12(07), 90-100.

Windschitl, M., \& Sahl, K. (2002). Tracing Teachers' Use of Technology in a Laptop Computer School: The Interplay of Teacher Beliefs, Social Dynamics, and Institutional Culture. American Educational Research Journal, 39(1), 165-205. 
Yildirim, S. (2007). Current utilization of ICT in Turkish basic education schools: A review of teacher's ICT use and barriers to integration. International journal of instructional media, 34(2), 171-186.

Zhao, Y., Pugh, K., Sheldon, S., \& Byers, J. (2002). Conditions for classroom technology. Teachers College Record, 104(3), 482-515.

Zhu, C. (2010). Teacher roles and adoption of educational technology in the Chinese context. Journal for Educational Research Online, II(2), 72-86. 